\title{
Housing: A Cyclical Industry on the Upswing
}

\author{
NEIL A. STEVENS
}

EW housing construction has been on the upswing since early 1975, following a severe downturn in 1973 and 1974. In many respects the current housing re covery is similar to other postwar recoveries, although apartment construction has not rebounded to the extent observed over similar periods in the past. Some perspective as to the nature of the current housing recovery can be gained by comparing its cyclical characteristics with those of previous recovery periods and by surveying the impact of several relevant economic variables on recent housing industry patterns.

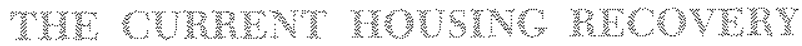

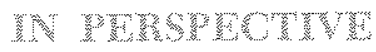

Historically, the housing industry has been characterized by recurring upswings and downswings which generally have been associated with fluctuations in overall economic activity. A sizable fluctuation in new home construction has been associated with each of the officially defined general business cycles in the past thirty years (see Chart I). ${ }^{1}$ In addition, the housing industry underwent an additional downturn in 1966, a period sometimes identified as a "credit crunch" or mini-recession for the general economy.

\section{Thinge}

Housing starts, a measure of new home construction activity, have generally led aggregate economic ac tivity in both the downswing and upswing phases of the business cycle. ${ }^{2}$ In the recessions experienced since 1945 , housing starts turned down from three to thirteen quarters before the economy in general, and turned up simultaneously with or as much as three quarters before overall economic activity. With regard to the current recession/recovery period, housing starts peaked in the fourth quarter of 1972 , some four

\footnotetext{
1The definitions of aggregate economic turning points ate those determined by the National Bureau of Economic Research (NBER).

2Housing starts, which are recorded at the beginring of excavation of the foundation of a building, are a measure of additions to the housing stock, though not a perfect measure. Housing starts, for example, do not include mobile homes which have become an increasingly important part of the housing stock. Also, housing starts are not standardized units with regard to size and quality. And, of course, a housing unit started does not necessarily yield a housing unit completed.
}

quarters before the peak in the general economy. The trough in housing starts was reached in the first quarter of 1975, the same as the apparent bottomingout point for the economy. ${ }^{3}$

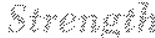

Although somewhat more rapid than many analysts had anticipated earlier, the rate of overall economic recovery has been about average when compared with other recoveries. ${ }^{4}$ The current housing recovery, however, has been regarded by some as average and by others as below average, depending upon the particular statistical comparison which is made.

Measured in terms of the percentage increase in the number of housing units started, the housing recovery through the second quarter of this year (a period of five quarters) has been about average when compared with similar periods in other postwar housing recoveries. ${ }^{5}$ The 46 percent increase in housing starts in the past five quarters is essentially the same as the 47 percent average increase recorded in the first five quarters of other postwar housing upturns. On an individual basis, housing recoveries have ranged from a 15 percent increase in the first five quarters following the housing trough in late 1960 to a 72 percent increase following the trough in early 1949 (see Chart II and Table I).

Despite the appearance of a fairly typical upturn in percentage terms, the level of housing starts in the second quarter of this year was below the average of previous recoveries at the five-quarter mark. At a seasonally adjusted annual rate of 1.43 million units in the second quarter of 1976 , the housing recovery to date is below the average level of 1.71 million starts for the same number of quarters in other postwar recoveries. In addition, the second quarter level of housing starts is 41 percent below the previous peak in late 1972 (see Table 1). While such comparisons give

3The NBER has not, as yet, selected the trough point for the aggregate economy it the last recession. The first quarter of 1975 is used here as a tentative date.

4For a discussion of the current economic recovery, see Roger W. Spencer, "Inflation and the Economic Recovery," this Review (June 1976), pp. 2-10.

"The duration of housing recoveries has varied widely, ranging from four quaters in two recoveries to eleven quarters in two other recoveries. 


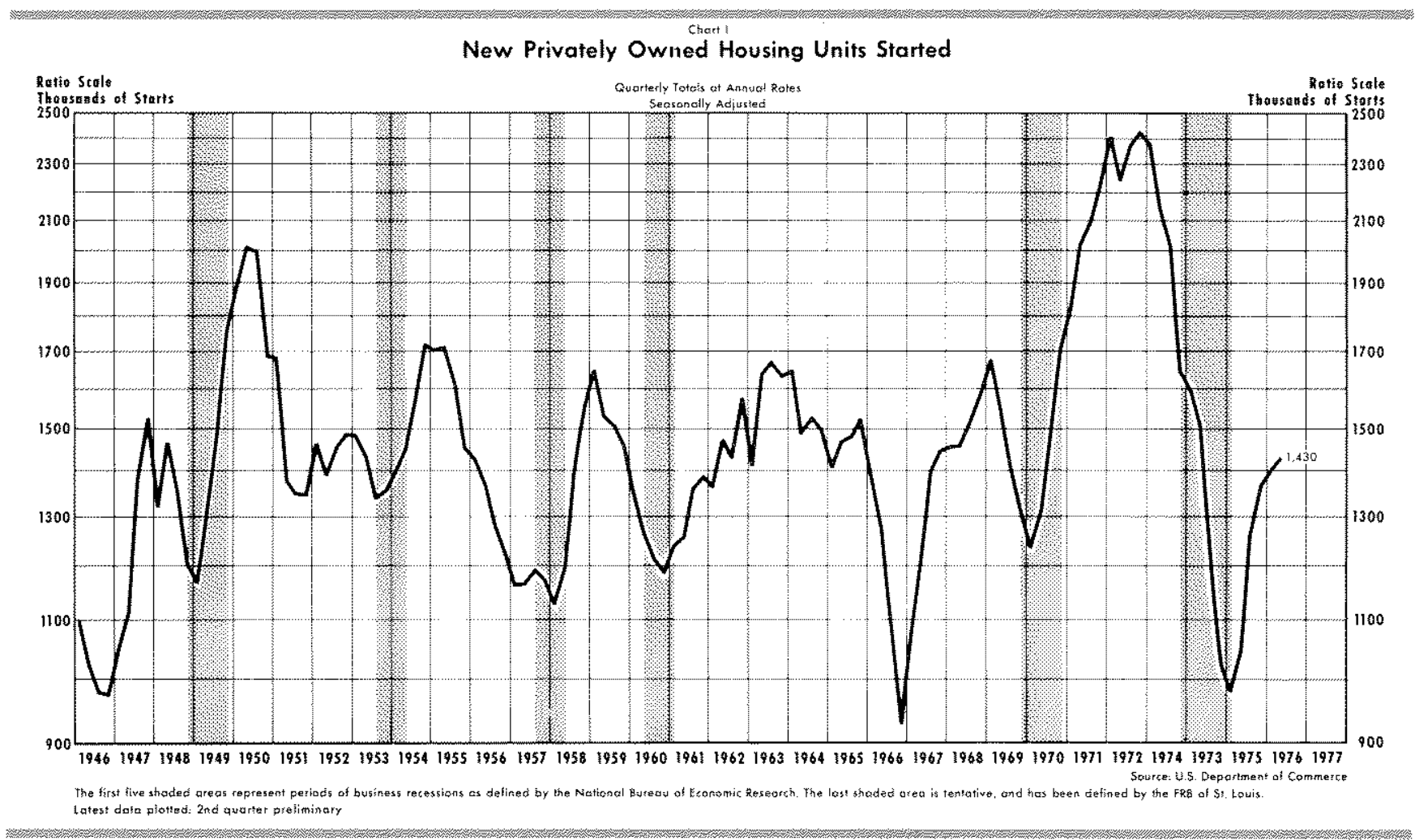

the impression that the current housing upturn is rather weak, it should be remembered that the peak in housing starts in late 1972 represented the highest level attained in the postwar period and that the trough in late 1974 represented the second lowest level.

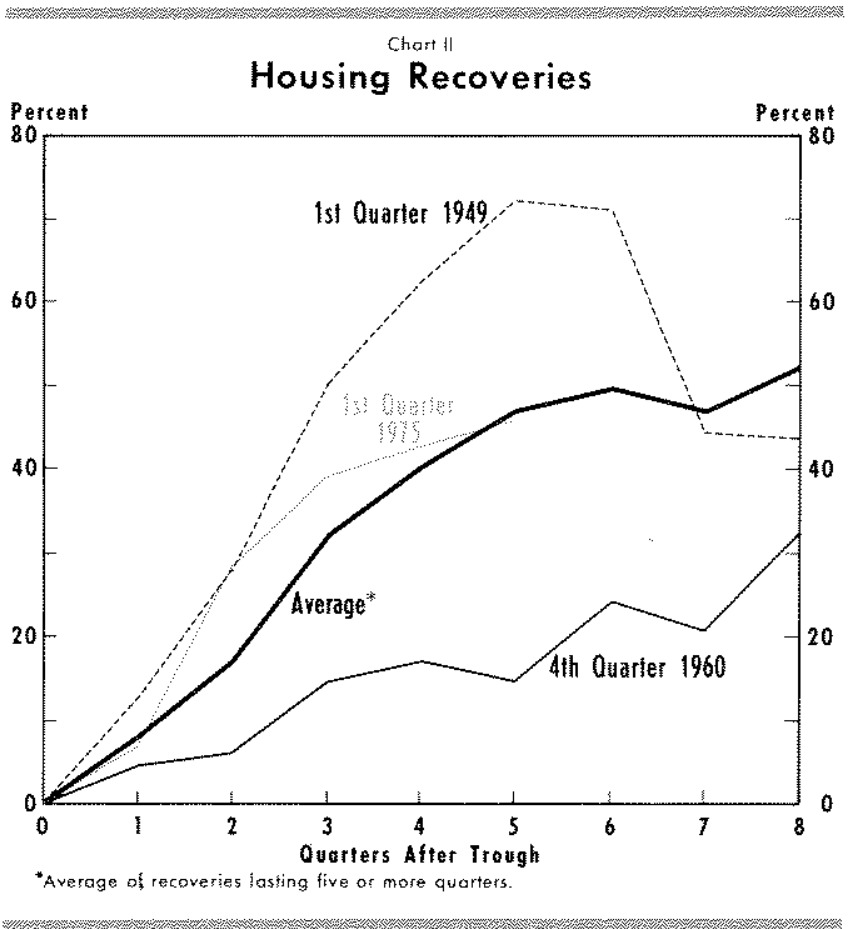

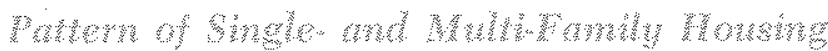

The current housing upturn has been dominated by construction of single-family dwellings, with the increase in single-family housing starts being over three times the increase in multi-family housing starts in the first five quarters of the present recovery. ${ }^{6}$ The gains in the two markets were considerably more equal in the three previous housing recoveries.

The recent paucity of multi-unit construction can be seen more clearly when viewed from a different perspective (Chart IV). Multi-family housing starts had trended upward relative to single-family starts over the $1959-73$ period; then the ratio of multi- to singlefamily construction plummeted from 83 percent in the third quarter of 1973 to 32 percent in the first. quarter of 1975. In the current expansion, this ratio has, on balance, remained at this low level, registering only 31 percent in the second quarter. In the three previous housing recoveries this ratio had generally risen.

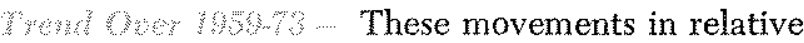
quantities of single- and multi-family housing reflect

GCondominiums, or owner-occupied apartments, have become an important share of multi-farnily housing starts, especially in the 1970s. In principle at least, such dwellings allowed owners to benefit from tax advantages and possible increased property values while retaining the amenities of apartment living. 
roble 1

\begin{tabular}{|c|c|c|}
\hline $\begin{array}{l}\text { Trough Quarer } \\
\text { Peok Quarter? }\end{array}$ & $\begin{array}{l}\text { Ourotion } \\
\text { (Quorters) }\end{array}$ & $\begin{array}{l}\text { percent } \\
\text { hicreane } \\
\text { from } \\
\text { Trough ro } \\
\text { Succeeding Peok }\end{array}$ \\
\hline $14 / 1946,1 \mathrm{~N} / 1947$ & 4 & $+56.6 \%$ \\
\hline $1 / 194911 / 950$ & 3 & 1723 \\
\hline $11 / 1953,1 / 1954$ & 5 & +2.8.2 \\
\hline $1 / 1958-1 / 1959$ & 4 & 1,461 \\
\hline $1 / 1060,11 / 1963$ & 11 & 1411 \\
\hline $1 Y / 960,1 / 969$ & 9 & 180.2 \\
\hline $1 / 1970, \mathrm{~W} / 1972$ & 11 & $+96,1$ \\
\hline Averags $1 / 1975$, 1,1976 & 5 & 460. \\
\hline
\end{tabular}

\section{ERIES IN HOUSING STARTS}

\begin{tabular}{|c|c|}
\hline 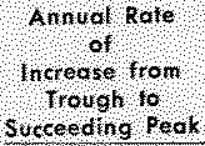 & 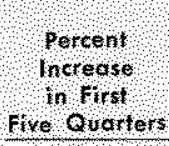 \\
\hline $1566 \%$ & $\mathrm{NA}$ \\
\hline $1+4,6$ & $1723 \%$ \\
\hline 12200 & 1282 \\
\hline+481 & $\mathrm{NA}$ \\
\hline 113 & 149 \\
\hline 1290 & $-56 \beta$ \\
\hline 1278 & 463,4 \\
\hline 1358 & +4702 \\
\hline अ? & 4458 \\
\hline
\end{tabular}

\begin{tabular}{|c|c|}
\hline 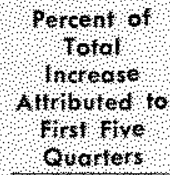 & 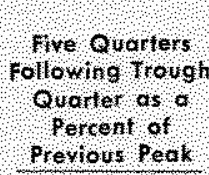 \\
\hline NA, & $\mathrm{NA}$ \\
\hline $100 \%$ & $1320 \%$ \\
\hline 100 & 14.8 \\
\hline $\mathrm{NA}$ & $\mathrm{NA}$ \\
\hline 36 & 3174 \\
\hline 70 & 43.0 \\
\hline 66 & +20.4 \\
\hline 742 & 16,02 \\
\hline $\mathrm{NA}$ & +4100 \\
\hline
\end{tabular}

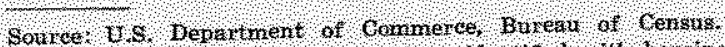

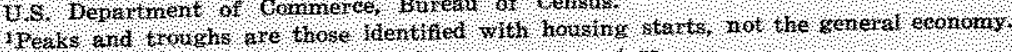

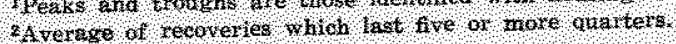

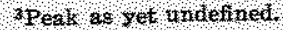

$\mathrm{N} \mathrm{A}, \mathrm{n}$ not andleable

changes in both demand and supply factors. In the 1959 to 1973 period, demographic factors were working in favor of increasing the demand for apartment housing relative to single family homes. Reflecting the post World War II baby boom, the number of people in the $15-29$ age group rose from 35 million to about 58 million from 1960 to $1975 .^{7}$ As a result, a large number of new households were formed among ages favoring apartment living. Rising income and changing social values also encouraged the formation of a greater number of single households. Apartment construction around colleges and universities, for example, proliferated in the latter 1960 s and early $1970 \mathrm{~s}$, and "singles" apartments became commonplace.

While such demand factors help explain the relative increase in multi-family starts during the 1959-73 period, a decline in the price of multi-family housing relative to single-family housing was also observed during this period. The rent component of the consumer price index, for example, rose 37.5 percent from 1959 to 1973 , compared with a 74 percent rise in homeownership costs. This change

7See George H. Brown, "Demographic Pressures for Change, "University of Michigan, Survey Research Center, Economic Outlook USA (Spring 1976), pp. 30-31. reflects, in part, different supply factors in the two markets. Little difference in cost of production can be attributed to such factors as labor or materials or from differences in production technique. How-

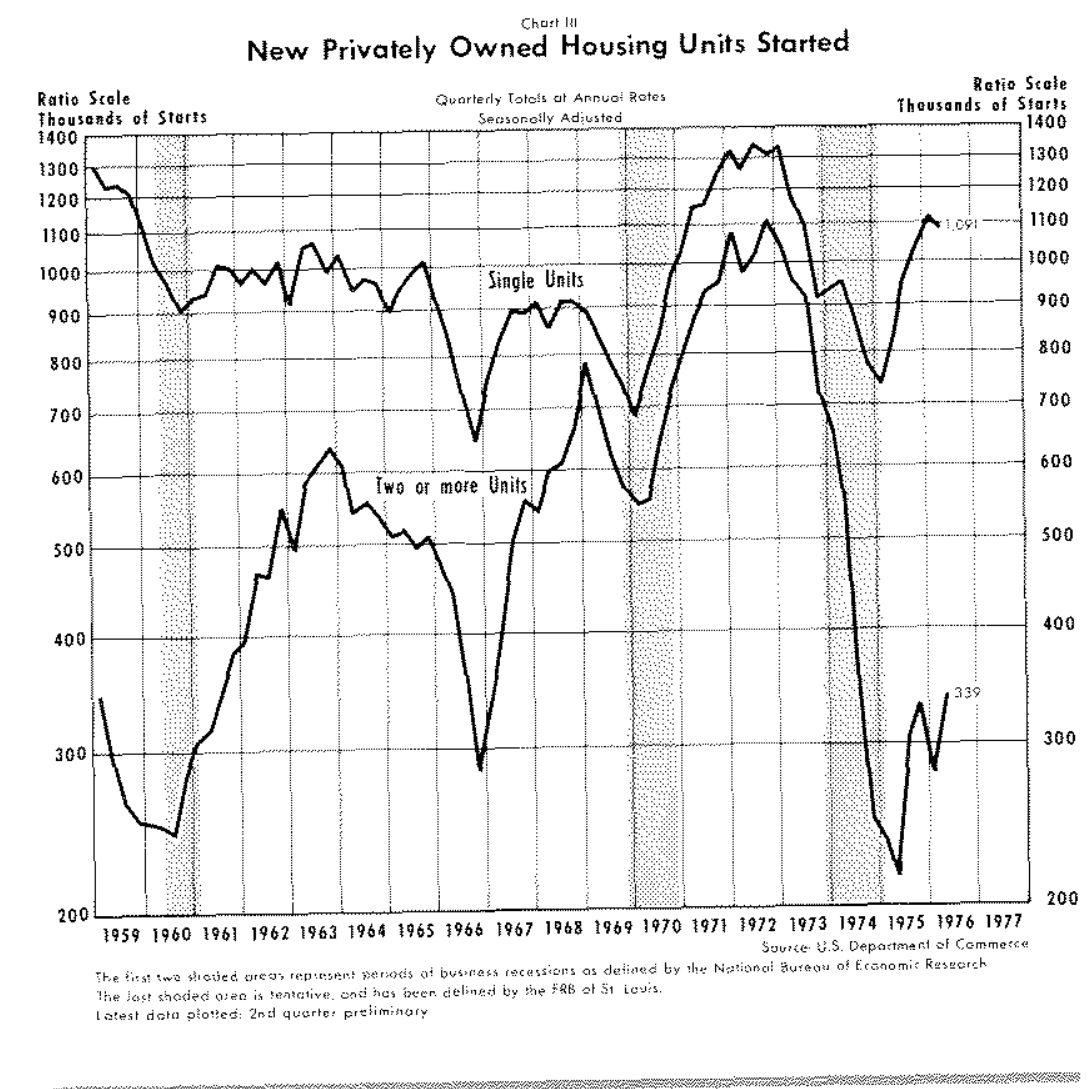


hoted iv

Prices and Production of Multi- and Single-Family Housing

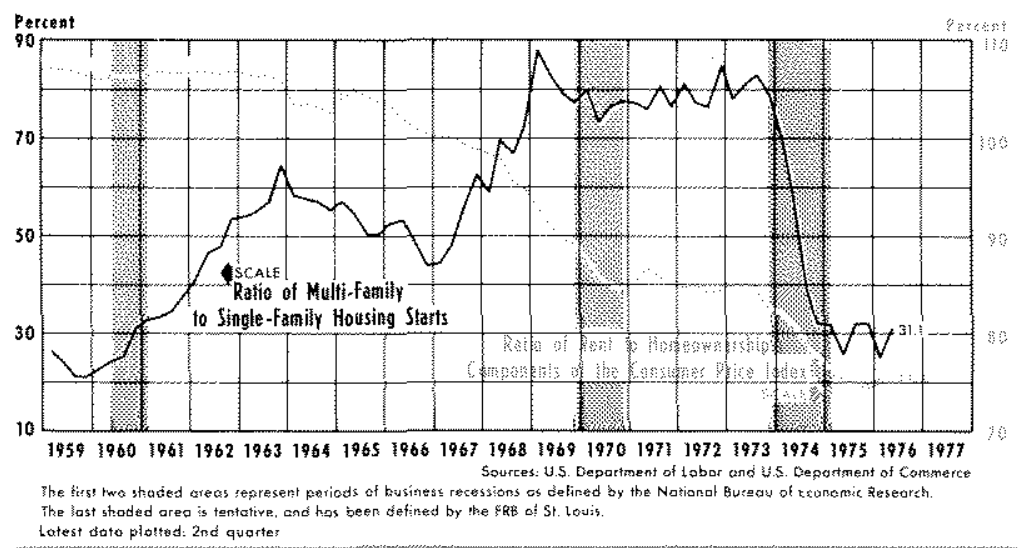

gested that one of the sources of the weakness in demand for apartments is related to these younger apartment dwellers simply returning home or "doubling up."

More recently, available evidence suggests that the demand for apartments has begun to increase. Vacancy rates have declined somewhat, and rents have risen at a 5.5 percent annual rate in the past six months, somewhat faster than the 3.1 percent rate of increase for homeownership costs. As the recovery continues, with rising real incomes and falling unemployment rates, the desire of younger persons for separate living quarters will likely be reasserted. Such events will, in turn, encourage the rent adjustment necessary if the construction of multi-family housing is to make substantial cyclical gains.

Demographic trends, however, argue against multifamily units regaining the prominence of the late $1960 \mathrm{~s}$ and early 1970 s. Based on Bureau of the Census projections, the 30-44 age group, which favors singlefamily homes, will rise sharply over the next fifteen years. Meanwhile, the number of people in the 15-29 age bracket is expected to decline slightly over the next fifteen years. Considering this trend factor alone, the demand for single-family homes will benefit relative to apartment demand over the coming years. On the other hand, the likely continuance of the upward trend in land prices will tend to favor apartments relative to single-family homes.

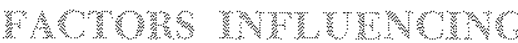 MONSW Grom}

to 5.7 percent in early 1973 . But why did apartment vacancy rates remain relatively high in 1975 , despite the tremendous decline in the construction of multifamily units, the attractiveness of renting versus homeownership costs, and generally improving economic conditions in the second half of 1975 ?

The evidence seems to imply that the excess supply situation in the multi-unit housing market was exacerbated by an unexpected decline in the demand for apartments, both absolutely and relative to singlefamily type housing during the recession period. The young people who were able to move out on their own in the late 1960s and early 1970 s as incomes rose were probably more severely affected by the economic decline in 1974 and early 1975 than the public in general. Real incomes declined for several quarters and unemployment among the young was much higher than for those who typically comprise the home-buying public. Some analysts have sug-

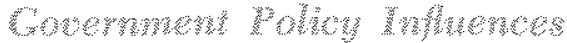

Fluctuations in new housing expenditures are closely associated with fluctuations in the general economy, but the factors which underlie such general economic fluctuations are a source of considerable disagreement among economists. Evidence has been accumu* lated which points to changes in the growth rates of monetary aggregates as a consistent factor underlying business fluctuations. ${ }^{9}$

\footnotetext{
sSee Alan R. Winger, "Whatever Happened to the Apartment Dwellers, ." Federal Home Loan Bank of Cincinnati, Quarterly Review (Second Quarter 1976).

9See Milton Friedman and Anna Schwartz, A Monetary History of the United States, 1867-1960, Princeton University Press, 1963; Milton Friednan, "Money and Business Cycles," Review of Economics and Statistics, pp. 32-64, Supplement, February 1963; Michael Keran, "Monetary and Fiscal Infutence on Economic Activity - The Historical Evidence," this Review (November 1969), pp. 5-24; Leonall C. Andersen
} 
Most economists would agree that monetary forces have important effects on the short-run behavior of the housing industry. A study by Francisco Arcelus and Allan Meltzer, for example, found that interest rates and the rental price of housing were principal factors determining the demand for new housing starts, while the chief factors determining the supply of housing starts were interest rates and labor costs. ${ }^{10}$ In that study, cyclical changes in interest rates of plus or minus 0.5 of 0.6 percent around a mean 5 percent market rate of interest were found to induce changes of 15 or 20 percent in the amount of new housing demanded."

In view of this alleged link between interest rates and housing, aiming Government policies at keeping interest rates "low" and stable in order to encourage home building seems appropriate to many individuals. The pursuit of such policies, without regard to the growth of the monetary aggregates, however, probably will lead to periodic economic recessions and inflations ${ }^{12}$ - both of which have damaging effects on housing.

Homebuilding, like the general economy, benefits temporarily from stimulative monetary policies, even if resources are essentially fully employed. But as these burgeoning demands for resources compete for the limited quantities available, upward pressures on prices result. In the competition, the demand for credit rises, partially reflecting inflationary expectations, and interest rates begin to increase, not fall as was originally intended. Indeed, it is during these so-called boom periods that the downward phase of the housing cycle typically has begun as the rising interest rates encourage consumers to postpone housing expenditures.

Public frustration with an unexpectedly accelerating advance in the price level leads eventually to policies designed to lessen the inflationary pressures. Monetary growth is reduced and, temporarily at least, interest rates rise even higher. The cutback in monetary growth leads to a reduction in aggregate spending, and temporary declines in income, employment, and production.

and Jerry L. Jordan, "Monetary and Fiscal Actions: A Test of Their Relative Importance in Economic Stabilization," this Review (November 1968), pp. 11-24.

10Francisco Arcelas and Allan If Meltzer, "The Markets for Housing and Housing Services," Journal of Money, Credit and Banking (February 1973), pp. $78-99$.

11 Ibid., p. 86.

$12 F$ or a recent discussion of some of these arguments, see William Poole, "Interest Rate Stability as a Monetary Policy Goal," Federal Reserve Bank of Boston, New England Economic Review (May/June 1976), pp. 30-37.
Housing, as was pointed out earlier, usually begins its recovery well before the upturn in the general economy. As the recession proceeds, general demand for credit recedes and interest rates begin to decline. As a result, during the latter stages of a recession and early months of the business recovery, housing historically has made its largest gains.

This process is exaggerated by several artificial restrictions on market behavior. For example, Government regulations on rates that thrift institutions can pay on time and savings deposits or rates these institutions can charge on loans have an important effect on housing activity. Housing is largely financed through credit extended by thrift institutions; therem fore, when interest rate ceilings become effective (that is, in periods of "high" interest rates) and funds are redirected into unregulated market instruments, the amount of credit available to finance housing expenditures is restricted. Similar effects result from the usury laws of various states. Credit naturally flows out of the regulated markets when market interest rates rise above the usury ceiling.

Although the cause and effect relationship is probably overemphasized, a high degree of correlation can be found among the amount of deposits at thrift institutions, changes in mortgages outstanding, and the number of new homes built. Even in the absence of interest rate restrictions, the rates offered by thrift institutions tend to adjust upward more slowly than market interest rates during periods of rising interest rates. Thus, the public tends to reduce its assets held at thrift institutions and to increase its assets held in other market instruments. Also, as interest rates rise, consumers tend to postpone housing expenditures and reduce their demands for mortgage credit. Thus, the positive relationship between changes in nonbank thrift deposits and changes in housing expenditures is observed without necessarily implying that one causes the other. ${ }^{13}$

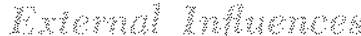

Recently, nonmonetary events also have led to fluctuations in economic activity by suddenly and unexpectedly affecting such economic variables as income, wealth, and relative prices. For instance, the sudden increase in oil prices in late 1973 and 1974 resulted in U.S. citizens having to export more goods and services for the same amount of oil as was previously received. Such a loss of wealth by U.S. citizens

13 See Arcelus and Meltzer for a further articulation of this view. 
and the accompanying one-time increase in the price level caused consumers and businesses to alter their spending decisions and thus contributed to the initial stages of the recent recession. Naturally, housing expenditures were also adversely affected by the losses in income and wealth.

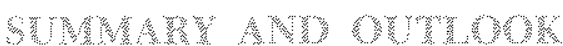

The housing sector is currently undergoing a recovery from the most severe decline since World War II. The current housing upswing did not lead the general economic upturn as in other recoveries, but, on balance, the percentage increase in housing starts to date is in line with the average of other postwar recoveries. The upturn has been primarily in the single-family type market, while the market for multifamily units, although posting some gains, has been sluggish.
Historically, the housing industry makes most of its gains in the late stages of the business recession and early quarters of the general economic recovery. Based on these historical patterns, the largest gains in the housing sector may have already been achieved. Yet, housing starts have not reached the level usually attained at this stage of the business cycle, particularly multi-family housing starts. A strong upturn in this market appears to depend on a further increase in the demand for such housing, which will signal increases in rents and induce a change in the quantity of housing starts. Over the coming decade, however, demographic factors are expected to favor increases in the demand for single-family homes. Age groups tending to prefer single-family dwellings are projected to increase substantially in the coming years, while age groups tending to favor apartments are expected to remain essentially unchanged. 